\title{
EXAMINING THE ISSUE OF ABOLISHING ENGLISH TUITION IN PRIMARY SCHOOL IN INDONESIA
}

\author{
Khairul Azmy ${ }^{1}$ \\ UIN Ar-Raniry Banda Aceh ${ }^{1}$ \\ azmykhairul99@gmail.com
}

APA Citation: Azmy, K. (2020). Examining the issue of abolishing English tuition in primary school in Indonesia. Language Research in Society, 1(1), 47-57.

Published:

02 May 2020

\begin{abstract}
This paper examines the reasons behind the philosophy of the Indonesian government's decision on abolishing English tuition in primary school. The Indonesian government has recently omitted English as compulsory tuition since English has been excluded in the curriculum at the primary level. The findings show that people have misinterpreted about whether English at the primary level is a compulsory, local-content or extracurricular tuition. In addition, it is found that teaching English at a young age is not practically efficient in Indonesia due to lack competence of teachers, unrelated syllabus and uninteresting teaching methods. Furthermore, the misconception of younger foreign language learners and cultural discrepancy are the other key findings in the issue provided. Ultimately, the implications of this article have given new insights on the issue of abolishing English tuition, whether it is effective or significant for primary students in Indonesia at this moment and condition.
\end{abstract}

Keywords: English tuition; primary school; abolishing English; local-content subject

\section{INTRODUCTION \\ Background}

It is inevitable that English has been utilised as the most widely spoken language for communication in a global context. Manara (2014) states that no nation can withdraw from the globalised used of English that notably change human's interaction and relationship to communicate nowadays. In addition, Mocanu and Vasiliu (2012) comment that English has taken over and controlled various aspects of human's life in general. It imparts a great responsibility to the education stakeholders to design and promote English in school curricula. Therefore, the implication of the use of English language such as on business, technology, school and universities, and entertainment has significantly affected policymakers to decide and prepare English curriculum in the educational system (Guilherme, 2017; Mocanu \& Vasiliu, 2012; Nguyen, 2017; Nunan, 2003). English is respected to have more benefits, prestige, and political power, which numerous countries determine to incorporate English in their school educational program (Lie, 2017).

Regarding the importance of English in the global context, it has influenced on the implications of the curriculum in the educational system (Guilherme, 2017; Mairi, 2016; Nunan, 2003). More countries have decided to put English in their curriculum started from primary to higher education. For example, Southeast Asian countries have established their curriculum and formulated English from primary school (Kirkpatrick, 2012). English tuition has been introduced for students from primary schools in some countries, including East and Southeast Asian nations (ASEAN) (Kirkpatrick, 2012). In addition, Nguyen (2011) points out that the policymakers have decided to make English a compulsory subject in the primary curriculum in Vietnam. Similarly, the new starting age to learn English has been upgraded to grade 1 in Kazakhstan (Zhetpisbayeva \& Shelestova, 2016). Furthermore, in order to make their students more competitive in the global context, Malaysian governments also put English in their 
primary curriculum (Darmi \& Albion, 2013). The expectation of those countries is exceptionally high to strengthen English for young learners.

In contrast to these views, having renewed the curriculum, the Indonesian government has omitted English as compulsory tuition for primary students. English is not taught in elementary school in Indonesia, and it has not become mandatory tuition for primary level students (Arif, 2015; Zein, 2016b). In this sense, English is only taught as an extracurricular subject at primary level in the context of Indonesia (Zein, 2017). It is argued that among Southeast Asian countries, only Indonesian government excludes English as compulsory tuition at the elementary level (Kirkpatrick, 2011; Kirkpatrick, 2012). Since the significance of learning English from a young age is crucially important, this new policy generates the debate among teachers, teacher educators, practitioners and stakeholders (Arif, 2015).

\section{Government and Policymakers' Reasons to Abolish English in Elementary Level in Indonesia}

In terms of Indonesian government policy, Indonesia has just renewed its curriculum from KTSP (School-based curriculum) into 2013 Curriculum. One of the implementations of the new 2013 curriculum is to abolish English as compulsory tuition at the elementary level (Arif, 2015; Zein, 2016b). Some education experts have stated several statements related to the reasons why the government and policymakers want to omit English in primary schools in the new 2013 curriculum. First, it is argued that the government intends to strengthen and brings more focus on Indonesian national language, Bahasa Indonesia subject to elementary level students (Hapsari, 2012). The exposure of English teaching in primary school has the potential for indigenous language loss since students demand to use English intensively (Hadisantosa, 2010). Thus, it is encouraged English in elementary becomes a secondary subject in order to provide more curricular space for Bahasa Indonesia. Another argument is that the government and policymakers assume English as a difficult subject to teach for elementary students. They consider it will be a burden if students are forced to learn English due to their cognitive immaturity and incompetence to learn a foreign language in early ages (Zein, 2017). Therefore, it is important for children to master linguistic competence in their first language instead of learning a difficult subject such as English. Another argument is highlighting a consideration of the government to accentuate firstly on national identity, Indonesian cultures and moral values rather than teaching English at primary school (Istiqomah, 2012). It is based on the regulation of Ministry of Education and Culture requires education to be implemented through national identity, cultural values, moral values, human rights and religious values (Ministry of Education and Culture, 2013).

Based on those reasons, English teaching education in elementary students has changed. This decision becomes a controversy and generates debates among many academic communities, such as teachers, researchers, and other education practitioners (Arif, 2015). On the one hand, some experts might regret about the new policy to remove English in the 2013 curriculum. For instance, Zein (2017) asserts that the language policy change might provide a framework for the development of instructions in teaching indigenous language, Bahasa Indonesia, for elementary school students. However, it appears to have a detrimental effect on neglecting English as a global language. Moreover, it is argued that abolishing English tuition may result in the inability of students' competence in learning a foreign language because it is not begun in early ages (Zein, 2016a). The earlier the students learn a foreign language, the better their achievement in acquiring the target language. On the other hand, some educators support the idea of abolishing English at primary level students. It is found that teachers' low proficiency and lack competency have made English become a difficult subject to be learnt and thus, the teaching activities have a minimum expectation from both teachers and students (Asriyanti, Sikki, Rahman, Hamra, \& Noni, 2013; Zein, 2016a). This lack of teaching competency has been pointed out as the major constraints on current students' achievement and results in learning English that is still deficient and unsatisfactory (Lestari, 2003; Zein, 2016b). 


\section{Significance}

In response to the above issue, the writer would like to critically examine the implications of the new 2013 curriculum on abolishing English in primary schools in Indonesia. The significance of the research is to reveal the English education, whether it is an appropriate decision or not to omit English at the elementary level in Indonesia. The paper also would like to explore clearly the reasons behind the philosophy of English abolition whether English should become compulsory tuition or an extracurricular subject in primary students. The result of this article is hoped to be a valuable source for policymakers, teachers and educators that can be used as the concept to re-examine the regulation on omitting English tuition. Moreover, it can be used as a useful insight to prepare neatly the practice of teaching English, such as teachers' qualifications so that the results will be more satisfactory in future learning practice.

In this essence, to give a clear understanding of the government's decision and policy, this article would first highlight the outline of critical ideas. The first essential key points are to critically evaluate the background of English status in primary schools in the Indonesian curriculum and followed by in-depth investigating the problems and challenges in teaching English at the primary level in Indonesia. In addition, this article then will scrutinise another idea on the concept of early ages in learning a foreign language, and it will continue to examine the cultural discrepancy on learning L2 critically. Ultimately, the article will be concluded by summarising the significant key points and giving further recommendations and implications practices for policymakers, teacher educators, teachers, and other practitioners based on the significance of the issue provided.

\section{Research Question}

Based on the issue provided, this article is guided by the following research question: what is the philosophy behind the reasons for the Indonesian government's regulation to abolish English tuition in primary school? By answering the question, it is hoped that it will uncover and reveal the decision of "why" the Indonesian government abolishes English subject to elementary students.

\section{METHOD}

This article is considered as a conceptual paper examining the existed literature reviews, in which some relevant topic from academic works were critically chosen and reviewed to find the information needed. The data analysis is conducted utilising secondary data analysis in which the data are gathered from previous literature from other articles (Bryman, 2016). In order to analyse the data, the current work assembled plenty of resources such as from reputable articles, books, academic journals and others in the area of elementary English education in the Indonesian context. Then, the selected literature was scrutinised and analysed critically regarding the relevant concept of abolishing English tuition in primary schools in Indonesia. Finally, the author evaluated and identified the results of existed literature to answer the research problem in this article and provide some possible recommendation and suggestions for future practice.

\section{RESULTS}

Based on the above research question, the result of the study critically scrutinized four main concepts regarding the philosophy of the Indonesian government's reasons for abolishing English in primary school. Firstly, the key point discussed how the status of English education in the curriculum to make clear whether English is a compulsory subject or not in primary education. Secondly, the result analysed the obstacles that both students and teachers face in English classroom activities. This investigation was based on the government's first reason stating that English is a difficult subject. Thirdly, the result examined the concept of learning a foreign language in early ages or "golden ages", in which some experts believed to be important for students' achievement. This analysis was related to the policymakers' reason pointing out 
primary students were not competent enough and ready to learn a foreign language. Finally, a cultural discrepancy was investigated to reveal the concept of cultural values and awareness for young students in learning a foreign language.

\section{The Status of English in Primary Curriculum}

The history of the status of English teaching in primary schools in Indonesia seems complicated. According to Zein (2016a), English language tuition is formally brought into Indonesian primary school "as a local content subject to students in Year Four through the Decree of Minister of Education and Culture No. 60/U/1993" (p . 423). Further, Zein (2016a) explains that the terms "local content" means English will be taught at schools based on the location as well as teachers' readiness in teaching English for some particular schools with starting age at grade 4 to 6 . In other words, English is not obligatory if the schools are located in rural areas that have a lack of proficient English teachers. However, having seen as a critical determinant of students' future achievement, the government begin to review an English curriculum. Therefore, a developing consciousness on the significance of English turns into the new policy to lower down starting age from grade 4 to 1 and put it into National Examination based on The Decree of Ministry of National Education No. 22/2006 (Zein, 2017).

In addition, the Ministry of Education and Culture of Indonesia has recently changed the curriculum from the School-based curriculum (KTSP) into the 2013 Curriculum. The recent curriculum has imposed the new status of English subject from local content to become an extracurricular subject (Zein, 2016b; Zein, 2017). This new implication implies that the instruction of English is not included in the required subjects to learn for examination and only be taught outside the major school hours (Zein, 2016b). In other words, English is not totally removed from the curriculum, and it is only changed and reduced the hours of learning instruction. Therefore, with regards to the status of English subject in Indonesian curriculum, there is a misunderstanding assumption to people about abolishing English tuition in the new 2013 curriculum regulation (Dewantara, 2014).

In summary, in this article, the author has highlighted the misunderstanding concept of removing or banning English from primary schools in Indonesia. It can be argued that English is not abolishing or omitting from the curriculum, but rather, it is still being taught in a different status. The government has designed English subject as local content tuition from the curriculum 1993 to 2006 and change the status into extracurricular since the education stakeholders proposed the 2013 curriculum. The pressure from parents and community shifts the paradigm of people regarding the transformation of English as if it were a compulsory subject in the primary curriculum (Rachmajanti, 2008). Therefore, there is a misconception idea of banning English in primary school.

\section{The Problems and Challenges in Teaching English at Primary School}

It can be argued that there are some obstacles and challenges to implementing English as a part of the core curriculum in the context of Indonesia. Firstly, the efficiency of learning English for primary students seems far from satisfaction in Indonesia due to the lack of competent English teachers (Hawanti, 2014; Lestari, 2003; Rachmajanti, 2008). The percentage shows that only a few English teachers have a qualification to teach English for primary students (Kasihani, 2007, as cited in Hawanti, 2014). Thus, there are two fundamental issues identified by Hawanti (2014) related to the capability of English teachers in elementary school, which are first most of the teachers have no background of English teaching skills, and secondly, those who have the qualifications are not prepared to teach in primary level. As a result, more unqualified teachers will take the rules to teach English without any background and knowledge (Rachmajanti, 2008; Lestari, 2003). Further, Lestari (2003) finds in her research that the majority of English primary teachers do not have sufficient language proficiency and low ability to improve their creativity in classroom management. It is indicated that most teachers and schools will have difficulty if English becomes an obligatory subject in the curriculum. Therefore, the implication of English 
as an extracurricular subject is the right decision for primary students levels in the context of teachers capability in Indonesia.

Secondly, in order to be successful in teaching English, the appropriate syllabus is needed to be constructed (Lestari, 2003). However, the main problem is that primary English teachers have difficulties in finding resources and materials that suitable to Indonesian cultural values (Zein, 2017; Hawanti, 2014). The materials and resources of English instruction are not designed to be efficient and adequate to multilingual students in Indonesia. In other words, the efficiency of material content does not meet students' need in enhancing their foreign language skills. Furthermore, it is hard to find the appropriate syllabus that makes teachers unable to design lesson plan in well-organised instruction (Lestari, 2003). As a result, due to no syllabus available, the teachers find and teach the materials based on the textbook that sometimes it is not proper and feasible to primary students level (Lestari, 2003; Hawanti, 2014).

The next obstacle is the ineffectiveness of teachers in presenting classroom activities. Numerous results maintain that English instruction in Indonesia has not meet a satisfactory result. For example, Rachmajanti (2008) asserts that most studies find disappointing with the methods and teaching strategies applied by teachers in the classroom. Mostly, teachers present traditional, conservative and monotonous methods such as memorising, asking and answering questions that create a dull classroom activities and inefficient to English instruction (Rachmajanti, 2008). Furthermore, Lestari (2003) points out that teaching and learning are not practical due to the learners have difficulty in comprehending English words. Hence, teachers utilise Indonesian or local languages when they speak and communicate with students that significantly will not improve language proficiency (Lestari, 2003). In brief, it can be stated that the effectiveness of learning English in Indonesia is still far from satisfying achievement. Therefore, it can be argued that the feasibility of English tuition in primary school is appropriate to be as an extracurricular subject in the Indonesian pedagogy context at this moment and condition.

\section{The Concept of Learning Foreign Language in Early Ages}

The analysis of how age affects students' skills in learning foreign languages have been discussed and debated by some researchers. There is a term namely critical period for early age to learn L2 which is considered that children will learn a second or foreign language faster than adults at that time (Larson-Hall, 2008; Marinova-Todd, Marshall, \& Snow, 2000; Nikolov \& Djigunović, 2006). However, the ideas of whether the age has a significant impact on L2 learning is still not clear enough that generates debate among researchers. On the one hand, Larson-Hall (2008) stated that age has an influence in learning the second language and recommends that children need to start to "study foreign language as young as possible with as many hours of input as possible" (p. 59). In other words, this view argues that the earlier and the more hours students begin to learn a foreign language, the better they achieve that language proficiency. On the other hand, Muñoz (2008) provides insight and shows that older age students also can learn a foreign language faster than younger learners. These two perspectives are interesting to investigate further because it has an impact on education. Therefore, it is crucial to analyse the concept of learning a foreign language in early age because it can affect the policy and practice in the educational system (Marinova-Todd, et al., 2000; Nikolov \& Djigunović, 2006).

According to the Indonesian curriculum, English as a foreign language will be taught at the secondary level (Manara, 2014). In this policy, the government has decided to begin L2 learning not in early age due to the belief that learning a foreign language can be accessed at the secondary level. In support to this concept, Marinova-Todd et al. (2000) claim that the ideas of a critical period are "misinterpretation, misattribution, and misemphasis" (p. 11). The views of younger foreign language learners will perform better than adult learners have been misinterpreted by the fact that adult students also could improve more than earlier learners (Marinova-Todd, et al., 2000). Further investigations, Marinova-Todd, et al. (2000) state that 
the neuroscientists have misattributed and given lack of evidence about the concept of how the speed of brain works to process language proficiency in younger and older learners. Furthermore, the most significant ideas are the misassumption on native-like competence. As the last concept of fallacies in early age L2 learning, Marinova-Todd, et al. (2000) put into account how people misunderstood that only younger learners can achieve the language performance as native-like. This misinterpretation concept is supported by Muñoz (2008) arguing that both younger and older learners can perform and acquire native-like in language proficiency.

In addition, people assume that adult cannot learn the second language as younger learner's proficiency. However, more support studies say that there is no significant effect on early age learning. For instance, Piehl (2011) asserts that the successfulness of learning a foreign language is not solely because of the age started, but more about learning goals. For example, motivation and efforts can determine someone's achievement in learning a foreign language. Further, Piehl (2011) indicates that the misconceptions and belief that adults cannot absorb the second language need to be reconsidered. For this reason, numerous language learning methodologies are developed and designed by educational experts for adults learners indicating that both young and adult learners could attain the same accomplishment in language proficiency (Piehl, 2011). Moreover, a study has been conducted by Muñoz (2011) discussing the impact of long-period learning for students to study a foreign language. He compared two groups of people who have learned a foreign language at an early age before 11 years old and those who learned at 11 above. The finding shows that there is no significant influence between these groups of students in learning foreign language skills (Muñoz 2011). In other words, the examination indicates that early starting age learners have no different results to those who start at older ages.

Nevertheless, in favour of time-consuming input, early age is considered to master a foreign language faster than adults, even the learners only have a minimum input of language proficiency learning (Larson-Hall, 2008). In her study, Larson-Hall (2008) found that early age foreign language learners have a significant impact on enhancing their language proficiency ability "even when input is only minimal" (p. 59). Therefore, her recommendation is to give more input in learning a language, and it can be accessed by starting learning a foreign language as early as possible (Larson-Hall, 2008). However, a contradictive result is found by Muñoz (2011), indicating that the minimal input of language proficiency could not enhance students' language proficiency even though they started at an early age. This finding supports the time limitation of English learning in Indonesia, which is only 70 minutes per week (Zein, 2017). In this case, Zein (2017) points out that although the students have started learning English from primary level, it will not affect anything on their language ability at the next level of education. Moreover, Nikolov \& Djigunović (2006) supports the ideas that it is not a guarantee that the long-time exposure learning can make students have better achievements in a foreign language.

In addition, regarding age pressures in learning a foreign language, related to the Indonesian government's reasons, English is considered as a complicated subject that will burden the students if it is implemented in primary level. In the Indonesian context, English has been abolished due to so many subjects that have to be learned by primary students, including English. Therefore, the government decides to reduce students' pressure by omitting the English subject. A study conducted by Aydin, Harputlu, Çelik, Uştuk, and Güzel (2017) concludes that younger learners feel more anxiety and more worried than adults' students when they learn a foreign language. Learning a foreign language can be very frustrating for students and may experience anxiety, burden and pressure for learners (Tran, 2012). Correspondingly, in their research, Liu and Chen (2013) found that elementary school are worried and feeling anxiety when they have to perform foreign language and the lack ability of speaking skills. Finally, in the context of Indonesian teachers' instruction, the traditional methodologies of English teaching, such as teaching grammar and dictating reading skill may lead to exposure and burden 
the elementary students (Rachmajanti, 2008). In brief, after analysing some studies related to age to learn a foreign language, this paper indicates that age has few effects on learning L2. Ultimately, having discussed English tuition in primary students level in the Indonesian context, it is believed that students will achieve more language proficiency if they learn a foreign language at the secondary level.

\section{Cultural Discrepancy}

Culture and language have significant roles on learning a language (Nguyen, 2017) and it cannot be ignored through the process of learning a foreign language (Kubota, 1998; Nguyen, 2017; Rochman, 2007). One of the reasons why the Indonesian government wants to abolish English is due to the fears of government on the harmful effect of cultural discrepancy for primary students. Since culture and language cannot be separated (Kubota, 1998), the government is worried about the English culture that might be imparted and engaged to the learners. This idea is supported by Rochman (2007), finding that concerning style and cultural aspects, most students on his research have a desire to be like English native speakers when they learn English. Further, Rochman (2007) indicates that some students tend to perform and utilise English as if English is their native language. Correspondingly, Kubota (1998) finds that these ideas and concepts also happen in Japan, when students learn English, they begin to act and think like native English speakers. This implication might affect students who learn English as foreign language especially for primary level students in the context of Indonesia.

In addition, it is important to consider that learning a foreign language can change students' perception of their own languages and values. For instance, in a particular Indonesian school, Manara (2014) found that the participants believe that the English language is more superior and prestige than Indonesian languages. Manara (2014) points out that it can potentially lead to the change of Indonesian language into English because when the school instructions use English in all subjects, Indonesian language becomes a "foreign language" to the students. As a consequence, in the context of Indonesian students, they may believe that the English language is more exceeding than their own languages. Similarly, Lie (2017) argues that the expanding predominance of English use for communicating has acquired the ramifications of cultural identity. In her study, Lie (2017) further finds that most participants assume that they tend to communicate and text the messages in English rather than Indonesian because English sounds more prestige.

Nevertheless, regarding cultural awareness, Nguyen (2017) argues about the ideas that students will be more aware and knowledgeable of other cultures and values through learning a foreign language. However, these ideas and concepts will happen when students are at a higher level. While at primary level, children try to imitate languages (Klinger, Mayor, \& Bannard, 2016) and have difficulty to separate whether it is from their own culture or other language values (Manara, 2014). Moreover, the effect of a habit to speak and communicate in English from early ages, people will tend to speak more in a foreign language than in their mother tongue (Mackay \& Fledge, 2004).

As a brief reflection, through the studies, it can be argued that there is a severe impact on culture discrepancy through learning a foreign language. It is further supported by the ideas of the materials and contents of English textbook are not feasible to cultural values in Indonesia (Zein, 2017; Hawanti, 2014). The books have more contents about other foreign stories and inappropriate for students at primary level. Hence, Indonesian policymakers have made the right decision to teach English in secondary, not in primary level, which is firstly focus on the Indonesian language before teaching students with other cultures. 


\section{CONCLUSION}

\section{Brief Summary}

In order to investigate the issue on removing English tuition at primary level in Indonesia, this paper has examined the background and the change of English curriculum and identified several key ideas to evaluate the effectiveness and feasibility of English subject in the context of Indonesian students. This article has proposed several important key points on the status of English in Indonesia and its misconception of the term "abolishing". It also highlights the problems, challenges, and obstacle such as teachers' competence, syllabus and material contents, and teachers' methods in teaching English at the primary level in Indonesia. Further, the paper has presented the concept of learning a foreign language in early ages which found that both younger and older learners can achieve the same achievements in language acquisition. Finally, the introduction of cultural discrepancy has been investigated through the perspective of the possibility of culture degradation for Indonesian students in the future. Based on the investigations, at this moment, it can be argued that English will be feasible as an extracurricular subject for primary students' level in the Indonesian context.

\section{Recommendations}

In this paper, the author believes that English is crucial to be taught for students. However, having seen the problems and contexts of Indonesia, it is hard to achieve a satisfactory accomplishment for elementary students at this condition. Therefore, in terms of recommendations, it is suggested that the government should enhance the training for English primary teachers in order to strengthen their skills to implement various strategies in teaching English. Further, the recommendation also proposes to policymakers, English educators and researchers to make an effort on conceptualising English syllabus and curriculum for primary students since in the future the students need to learn English to compete in globalisation.

Finally, the investigation is hoped to give new insights and perspectives on the issue of abolishing English tuition, whether it is effective or significant for primary students in Indonesia at this moment and condition. It is expected that the Indonesian government could provide teachers with training to primary English teachers. Furthermore, it is also demanded that the policymakers, teacher educators and researchers to invent suitable approaches and proper syllabus for English at the elementary level in Indonesia.

\section{ACKNOWLEDGMENT}

This article is derived from the university assignment paper written by the author at Monash University, Australia. The author would also like to show his gratitude to The Indonesian Endowment Fund for Education (LPDP) Scholarship for the grant given to the author in this paper.

\section{REFERENCE}

Arif, N. (2015). Removing English as compulsory subject from primary schools on the 2013 curriculum based on teachers'. International Journal of Scientific and Research Publications, 5(8).

Asriyanti, E., Sikki, A., Rahman, A., Hamra, A., \& Noni, N. (2013). The competence of primary school English teachers in Indonesia. Journal of Education and Practice, 4(11), 139 146.

Aydin, S., Harputlu, L., Çelik, Ş. S., Uştuk, Ö., \& Güzel, S. (2017). Age, gender and grade effect on foreign language anxiety among children. TEFLIN Journal, 28(2), 133-154.

Bryman, A. a. (2016). Social research methods (Fifth edition. ed.). Oxford University Press. 
Darmi, R., \& Albion, P. (2013). English language in the Malaysian education systems: Its existence and implications. Paper presented at Malaysian Postgraduate Conference (MPC 2013), New South Wales. Retrieved from http://www.academia.edu/4275280/English_language_in_the_Malaysian_education_ system_Its_existence_and_implications

Dewantara, C. (2014). Dilema penghapusan mata pelajaran bahasa Inggris di sekolah dasar [The dillema of abolishing English tuition in Primary School]. Retrieved April 28, 2014, from https://www.kompasiana.com/charisdewantara/dilema-penghapusan-matapelajaran-bahasa-inggris-di-sekolah-dasar_54f77a9da33311f96c8b4584

Guilherme, M. (2007). English as a global language and education for cosmopolitan citizenship. Language and Intercultural Communication, 7(1), 72-90. doi:10.2167/laic184.0

Hadisantosa, N. 2010. 'Insights from Indonesia'. In R. Johnstone (ed.), Learning through English: Policies, Challenges and Prospects. British Council, pp. 24-46.

Hapsari, A. (2012). Polemik pelajaran bahasa inggris di kurikulum SD [The polemic of English lesson in primary curriculum]. Retrieved from http://www.sekolahdasar.net/2012/11/polemik-pelajaran-bahasa-inggrisdi.html\#ixzz2tcoedkzm

Hawanti, S. (2014). Implementing Indonesia's English language teaching policy in primary schools: The role of teachers' knowledge and beliefs. International Journal of Pedagogies and Learning, 9(2), 162-170. doi:10.1080/18334105.2014.11082029

Istiqomah, F. (2016). Reintroducing the importance of teaching English at primary schools in Indonesia. Lingua Scientia, 8(1).

Kirkpatrick, A. (2011). English as an Asian lingua franca and the multilingual model of ELT. Language Teaching, 44(2), 212-224. doi:10.1017/S0261444810000145

Kirkpatrick, A. (2012). English as an Asian lingua franca: the 'lingua franca approach' and implications for language education policy.Journal of English as Lingua Franca 1(1), 121-139. doi:10.1515/jelf-2012-0006

Klinger, J., Mayor, J. and Bannard, C. (2016), Children's faithfulness in imitating language use varies cross-culturally, contingent on prior experience. Child Dev, 87, 820-833. doi:10.1111/cdev.12503

Kubota, R. (1998). Ideologies of English in Japan. World Englishes, 17(3), 295-306. doi:10.1111/1467-971X.00105

Larson-Hall, J. (2008). Weighing the benefits of studying a foreign language at a younger starting age in a minimal input situation. Second Language Research, 24(1), 35-63. doi: $10.1177 / 0267658307082981$

Lestari, L. A. (2003). Should English be a compulsory subject in the elementary schools?, Jurnal Bahasa dan Seni, 31(2), 197-213.

Lie, A. (2017). English and identity in multicultural contexts: Issues, challenges, and opportunities. TEFLIN Journal, 28(1), 71-92. doi: 10.15639/teflinjournal.v28i1/71-92 
Liu, H.-J., \& Chen, T.-H. (2013). Foreign language anxiety in young learners: How it relates to multiple intelligences, learner attitudes, and perceived competence. Journal of Language Teaching and Research, 4(5), 932.

MacKay, I. R., \& Flege, J. E. (2004). Effects of the age of second language learning on the duration of first and second language sentences: The role of suppression. Applied Psycholinguistics, 25(3), 373-396. doi:10.1017/S0142716404001171

Mairi, S. (2016). An english as a lingua franca (ELF) perspective in asian english language teaching. Chinese Journal of Applied Linguistics, 39(4), 401-420. doi:http://dx.doi.org.ezproxy.lib.monash.edu.au/10.1515/cjal-2016-0026

Manara, C. (2014). "That's what worries me": Tensions in english language education in today's indonesia. International Journal of Innovation in English Language Teaching and Research, 3(1), 21-35,110.

Marinova-Todd, S., Marshall, D., \& Snow, C. (2000). Three misconceptions about age and L2 learning. TESOL Quarterly,34(1), 9-34. doi:10.2307/3588095

Ministry of Education and Culture (2013). Peraturan Menteri Pendidikan dan Kebudayaan Republik Indonesia Nomor 65/2013 tentang Standar Proses Pendidikan Dasar dan Menengah. [The Regulation of the Minister of Education and Culture of Republic Indonesia Number 65/2013 concerning the Process Standard of Education in Elementary and High School]. Jakarta: Author.

Mocanu, M., \& Vasiliu, E. (2012). English as a global language methodological challenges and perspectives. Euromentor Journal, 3(4), 84-91.

Muñoz, C. (2008). Age-related differences in foreign language learning. Revisiting the empirical evidence. IRAL - International Review of Applied Linguistics in Language Teaching, 46(3), 197-220. doi:10.1515/IRAL.2008.009

Muñoz, C. (2011). Input and long-term effects of starting age in foreign language learning. IRAL - International Review of Applied Linguistics in Language Teaching, 49(2), 113-133. doi:10.1515/iral.2011.006

Nguyen, H. T. M. (2011). Primary English language education policy in Vietnam: Insights from implementation. Current Issues in Language Planning, 12(2), 225-249. doi:10.1080/14664208.2011.597048

Nguyen, T. T. T. (2017). Integrating culture into language teaching and learning: Learner outcomes. The Reading Matrix: An International Online Journal, 17(1).

Nikolov, M., \& Djigunovic, J. M. (2006). Recent research on age, second language acquisition, and early foreign language learning. Annual Review of Applied Linguistics, 26, 234260.

Nunan, D. (2003), The Impact of English as a global language on educational policies and practices in the Asia-Pacific region. TESOL Quarterly, 37, 589-613. doi: $10.2307 / 3588214$

Piehl, K. (2011). Can adults learn a second language? Research findings and personal experience. Delta Kappa Gamma Bulletin, 78(1), 33-37. 
Rachmajanti, S. 2008. Impact of English instruction at the primary school on the students' achievement of English at the lower secondary school. TEFLIN Journal, 19(2), 160185. doi: 10.15639/teflinjournal.v19i2/160-185

Rochman, S. (2007). Researching language aspects' preferences of english department students when learning culture. $K @ t a, 9(1), 49-59$.

Tran, T. T. T. (2012). A review of horwitz, horwitz and cope's theory of foreign language anxiety and the challenges to the theory. English Language Teaching, 5(1), 69-75.

Zein, M. (2017). Elementary English education in Indonesia: Policy developments, current practices, and future prospects: How has Indonesia coped with the demand for teaching English in schools? English Today,33(1), 53-59. doi:10.1017/S0266078416000407

Zein, S. (2016a). Factors affecting the professional development of elementary English teachers. Professional Development in Education, 42(3), 423-440. doi:10.1080/19415257.2015.1005243

Zein, S. (2016b). Pre-service education for primary school English teachers in Indonesia: policy implications. Asia Pacific Journal of Education, 36(sup1), 119-134. doi:10.1080/02188791.2014.961899

Zhetpisbayeva, B. A., \& Shelestova, T. Y. (2016). Examining teachers' views on the implementation of english as L3 into primary schools: A case of kazakhstan. International Electronic Journal of Elementary Education, 8(4), 659-673. Retrieved from https://search-proquest-com. 